\title{
The Concept of Re-Creation of Persian Garden Privacy in Mosque Design
}

\author{
Safoora Rahmani Miyandehi ${ }^{*}$, Azadeh Rahmani ${ }^{2}$, Azadeh Khaki Ghasr ${ }^{3}$ \\ ${ }^{1}$ Graduated from Art \& Architecture School, Yazd University, Yazd, Iran \\ 2 Graduated from Dr Shariaty Uiversity, Tehran, Iran \\ ${ }^{3}$ Assistant Professor at Department of Architecture and Urban Planning, Shahid Beheshti University, Tehran, Iran
}

\begin{abstract}
One of the primary goals in mosques design is to connect the users to Allah. By accepting privacy as an origin to approach to that, the question notices properties and dimensions of privacy in Persian gardens as great examples of private places in Islamic Iranian architecture. Next question follows orders create privacy affordance to them. The results shows orders are: Light, color, sound, material, and air condition orders. Finding orders have been linked to mosques design through recommendations which focus on preparing privacy and community together, based on Islam worship order. The methodology is descriptive, analytical and observational.
\end{abstract}

(C 2016. The Authors. Published for AMER ABRA by e-International Publishing House, Ltd., UK. Peer-review under responsibility of AMER (Association of Malaysian Environment-Behaviour Researchers), ABRA (Association of Behavioural Researchers on Asians) and cE-Bs (Centre for Environment-Behaviour Studies), Faculty of Architecture, Planning \& Surveying, Universiti Teknologi MARA, Malaysia.

Keywords: Privacy, Persian gardens; re-creation; mosques design

\section{Introduction}

Mosques are places to gather Muslims to pray. It is used to point to a place which no one possesses and is dedicated to Allah and to pray and worshiping God (Hariri, 2009). The necessity to the presence of the believer's heart is to be in community of people and observe religious rituals while he/she is in his/her privacy. The consequence of the contemplation on himself and divine signs is reaching spirituality and being in connection to God. Nature as the most comprehensive source of divine signs is a sacred mechanism which makes humankind contemplates on himself and connecting to God. Due to this, it is intended to use natural blessings and providing believers with required privacy for connecting to God and appropriate atmosphere to contemplate in mosques design. It seems refer to nature would be an appropriate tool to achieve essence of Persian gardens to accomplish the task in the research.

A necessary condition to hear the voice of existence is to hear the inner voice. To do so, one must contemplate and has selfinquiry. By accepting Persian gardens as some of existence manifestations, it would be said that they give us an opportunity to

\footnotetext{
${ }^{*}$ Corresponding author. Tel.: +0-000-000-0000

E-mail address: sa.rahmani.m@gmail.com
}

(c) 2016. The Authors. Published for AMER ABRA by e-International Publishing House, Ltd., UK. Peer-review under responsibility of AMER (Association of Malaysian Environment-Behaviour Researchers), ABRA (Association of Behavioural Researchers on Asians) and cE-Bs (Centre for EnvironmentBehaviour Studies), Faculty of Architecture, Planning \& Surveying, Universiti Teknologi MARA, Malaysia.

DOl: https://doi.org/10.21834/e-bpj.v1i2.285 
hear the voice of the existence. So, "Persian garden enjoys a peaceful quality and provides mankind with privacy and inviting him to contemplation (Shahcheraghi, 2010). In this research it will be discussed how Persian gardens could be a responsive model of preparing privacy affordance to mosques designs guidelines.

Persian gardens have great affordance which is to increase sensations. So, there is richness. The aim of the study is to recreate privacy of Persian gardens for strengthening the connection of human being to Allah. Here, re-creation means to apply methods and practical experiences of our ancestors and put them to practice to design the qualitative way of living. In this study, authors try to review the procedures used for mindfulness in Persian gardens to approach to privacy. The external validity of study refers to needs of new mosques construction all over the world. Furthermore, the goal of the study is to promote quality of worship which has intersection to architecture.

\section{Literature Review}

\subsection{Privacy related to Worship}

Providing privacy is the necessity of the believer's presence of heart to pray and worship his/her God. He/she then will reach spirituality and make a connection with God. In addition to religious rituals, the private atmosphere provides the opportunity to contemplate, meditation, and self-inquiry for each individual.

\subsection{Privacy in behaviouristic sciences}

In terminology of behaviouristic sciences privacy contains equivalences such as Personal Independence, Emotional Evacuation, Self-Assessment, control and preserve relations and limitation of them (Westin, 1967). Other similar terms are personal ability to define limitations and borders around, monitoring reciprocal relations, Self-Observing and personal identity (Altman, 1975). Solitude, or the condition of being alone, is the most commonly used term for the definition of privacy. In solitude, an individual is separated from others (m.n. Gharaeia, 2012). In Islamic mysticism, the goal of mystical privacy is to let human beings contemplate on the self to connect to the truth. Therefore, keeping distance from human beings is an opportunity for affinity to God (ZafarNavai, 2010). Each definition related to privacy, several features could be observed. The main idea behind these definitions is an individual ability to control his/her visual, auditory and olfactory interaction in relation to other mankind (Lang, 1987). The cornerstone of Persian garden is its privacy to focus on attention and five senses. Therefore, in the paper authors try to find functions to monitor and control five senses to approach to privacy

\subsection{Privacy in some examples of Iranian Islamic Architecture}

Creating of a suitable space for solitude and contemplation has been always one of the tenets of Iranian architecture. In Islamic Sufism, "Solitude" and reaching the timeless truth, is considered reaching the eternal peace and sinking into the ocean of divine unity (Ghanaati, 2015) Different manifestations of Privacy in Persian architecture are like corners of monasteries, caravanserais, mosques, houses and etc. A corner is an environment which provides the prayer with a place in where he/she can meditate, contemplate and worship God. The term "Corner" is used to convey the meaning of a quiet private sector at a corner for humankind to worship God (Kiyani, 1990). The corner may possess an altar (G. Bidhendi, 2014) or it may be under a roof or owns a small dome. In Iranian architecture a place which is devoted to worship, privacy and relaxation for affinity to God is called a retired or private place (Beheshti, 2009). In Iranian mosque, movement along the direction of Kiblah ${ }^{\mathrm{i}}$ by enhancement of elements such as rhythm view, water and gardens, reaching the stillness of Gonbadkhaneh ${ }^{\text {ii }}$ and then directing the glance to the top can mean a feeling of lightness due to a sacred presence for human (Ghanaati, 2015) Persian garden is another kind of private place examples. In such place, one can enjoy the opportunity to relax and contemplation. 


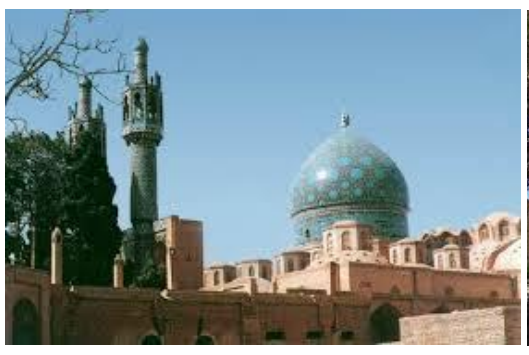

Fig.1. Shah-Nematollah-Vali

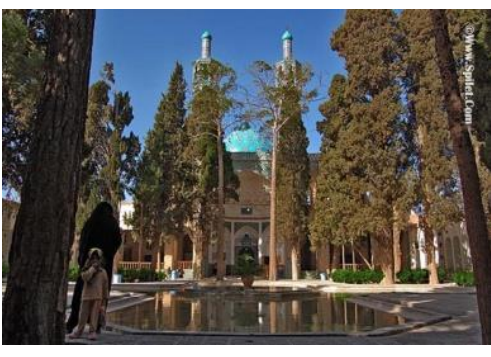

Fig. 2. Garden-Monastery

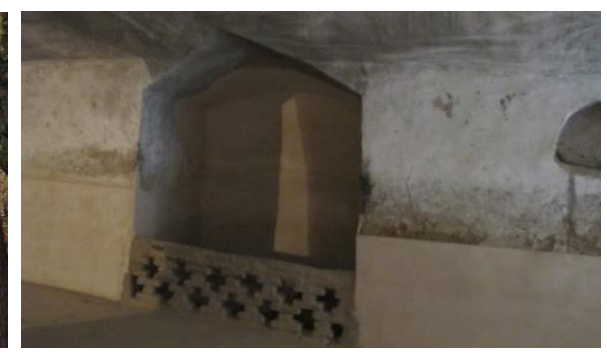

Fig. 3. A Corner in Na-ein cathedral mosque

\subsection{Privacy and physical orders of Persian gardens}

In Persian gardens, architecture orders are the regulatory components of functional, physical and meaning-based orders. Mindfulness which is the consequence of main directive order and perception system of attention would put emphasis on sensation and besiege of perception (Shahcheraghi, 2010). Physical orders of the garden include aqua order, planting \& building order, which are effected by geometrical order of the garden. Focusing on five senses (Visual, Auditory, Tactile, Olfactory and Taste) would separate the person from the outer environment and bring about peace for him/her. By mindfulness, an individual can contemplate and meditate. Then by using experience and direct or indirect perception of the cultural environment, individual can release the meaning of garden. Providing peace and required privacy would invite him/her Self-Inquiry and Self-Observing.

\section{Methodology}

In this paper, the authors have reviewed privacy and its affordances in Persian garden. To achieve the goal of the study and presenting appropriate recommendations to designers of mosques, the authors have investigated its influence on senses by referring to which factors exist in Persian garden. For the first step, the architecture orders which are in Persian garden order related to achieving privacy should be explained. Then the effect of them on human being should be described.

\subsection{Worship definition in Islam}

As Holy Quran says, the term "Mosque" is defined as a place to pray and sometimes it is defined as the place of altar or worship (Hariri, 2009). Worship means to pray Allah in a modest, humble and courtesy manner (Dehkhoda, 1998). Morteza Motahhariiii (1920 -1979) has defined worship: "Worshiping is a manner in which man is paying attention heart to the truth which created him and sees himself in grasp of his potent. He sees himself in need of Allah. This is a journey of creatures to the Creator. This is basically a necessary need of human beings "(Motahari, 2010). The act of worship in Islam is performed individually or collectively. Reading Quran, praying, studying, thinking and contemplation are the examples of worship.

\subsection{Properties and dimensions of privacy in worship}

Perception of privacy in worship is effective beside its partner which is perception of community. In other word, a person in a community and collective worship needs a place of private nature to contemplate. Therefore, in Islam both privacy and being among people are needed to pray and worship in mosques. So an essential origin to design of mosques is worship order through achieving privacy and community. The properties of privacy in worship order and their dimensions have been noticed in below Table1. 
Table 1. Properties and dimensions of privacy in worship

\begin{tabular}{llll}
\hline The properties & Focus on worship & Separateness of others & Connection to Allah \\
\hline \multirow{2}{*}{ The dimensions } & $\begin{array}{l}\text { From notice to say prayer to } \\
\text { presence of heart }\end{array}$ & $\begin{array}{l}\text { From not hear or see others to } \\
\text { not think to others }\end{array}$ & $\begin{array}{l}\text { From decreasing cognition distance of man to } \\
\text { Allah To approach to sense of eternity }\end{array}$ \\
\hline
\end{tabular}

\subsection{Worship orders in mosques}

Altar, collective unity and privacy in mosques are all derived from the worship order. Other orders pertaining to mosques are in harmony and concordance with the worship order and they all lead to the promotion of the worship quality. In worshipping orders, the voice of mantras, silence, and together say to pray will form an order of voices which would influence spirituality through the auditory sense and directly trigger the believer's heart. The Altar Order means a hidden spatial subpart in front of which the people would worship God. It consists of the altar and surrounding walls. The structure can be placed in "Shabestan"iv, the courtyard of the mosque of the private sector. In this definition, we assume the main wall facing "Kiblah". The Community Order means a hidden spatial subpart of the mosque to collective actions especially congregational prayers. The Privacy Order means a hidden spatial subpart which provides places to solitude and individual worship.

\subsubsection{The quantitative orders}

In this study, quantitative orders refer to environmental condition. Light, sound, and air condition orders and etc. are all derived from the environmental condition in the quantitative orders. A peaceful environment is an important exterior factor which would influences the quality of worship. The environment must not be something incongruous with the sacred status of the mosque which results in mental disturbance (Razjouyan, 2001). Temperature, moisture and interior and exterior disturbing sounds and unpleasant smells would result the lack of focusing and presence of heart. Also uncontrolled natural and fake lights can effect on the occasion. By controlling these parameters, the level of presence of heart would be increased.

Light and brightness are orders defining perceptual atmosphere and explaining the geometry. Brightness and light include aspects of physical, mental and meaningfulness. In orders pertaining to environmental conditions related to mosques, the physical and mental aspects are noticed naturally. Light as a factor to see things has influence on the visual sense. The place and way of the lights' entrance, intensity of rays, light's reflection and absorption and also lights and shades effects will influence the privacy and presence of heart. Therefore, in the place of worshipping we must take into account the location and ways applied for natural and superficial lights and choosing materials. We should be careful not to disturb the privacy. It is noteworthy to mention that changing shades and brightness and its influence on the skin will result in different sensory interpretations of tactile sense.

The sound is an influential factor on individual's perception of space. In mosques, reflection and absorption of sounds in each space and transmitting it from one space to another one will affect the mental confusion or peace. The kind of material used in the structure will influence acoustic and physical feature of sound. Therefore, choosing materials and interior design are determining factors for controlling sound. The sound order will influence the privacy through auditory order.

Air conditioning in mosques is of natural or artificial nature. Temperature is a determining factor in the personal experience of the crowd (Hall, 1966). Therefore, air conditioning order will influence mindfulness. Also, air conditioning order will influence on olfactory sense through controlling unpleasant smell and perfume. Proper air conditioning will influence the person's feeling of heat or cold. Due to this fact, air conditioning will affect tactile sensory.

\subsubsection{Qualitative orders}

Qualitative orders refer to ornaments. The material arrangement, light, and colour orders and etc. are inside the qualitative orders Ornaments in mosques are influential, essential and inseparable. The figure is an inseparable product of materials. Colour will not appear by itself unless it is in harmony with the figures. The light will manifest the colour of the figures. So the depth of perspective will appear in understanding of the observer. In Qualitative orders, the meanings of light are intended. 
The first effect of ornaments of presence, colour and figures is in the visual sense. The dimension of material arrangement will influence tactile sense through touching body organs. Ornaments will influence auditory sense through reflection, absorption and transmission of sound waves.

\subsubsection{Orientation order}

Religious rituals in Islam are performed in the direction of Kiblah, the Kaaba in Mecca. Therefore, Kiblah is directing foundation of mosques. Lack of capability for finding spatial directions will lead to mental disturbance (Hall, 1966). Therefore, emphasis on Kiblah Direction and harmony with other orders of the mosque will have the influence on mindfulness. Geometrical structure of mosques is naturally in harmony with worshipping order and Kiblah direction. In the way of the regularity of mosque space, a hierarchy for progression toward perfection should be observed. (Ghanaati, 2015). The hierarchy of the entrance of the mosques would be more suitable to prepare the boundary of reciting exhortation of the mosque and boundary of the city itself for preparing minds. Therefore, by using environmental factors, mental disturbance would be decreased to some extent. Man could get ready to enter the Holy area of mosques. Applying principles of besiegement in Persian gardens to direct toward Kiblah can be an influential parameter to provide privacy.

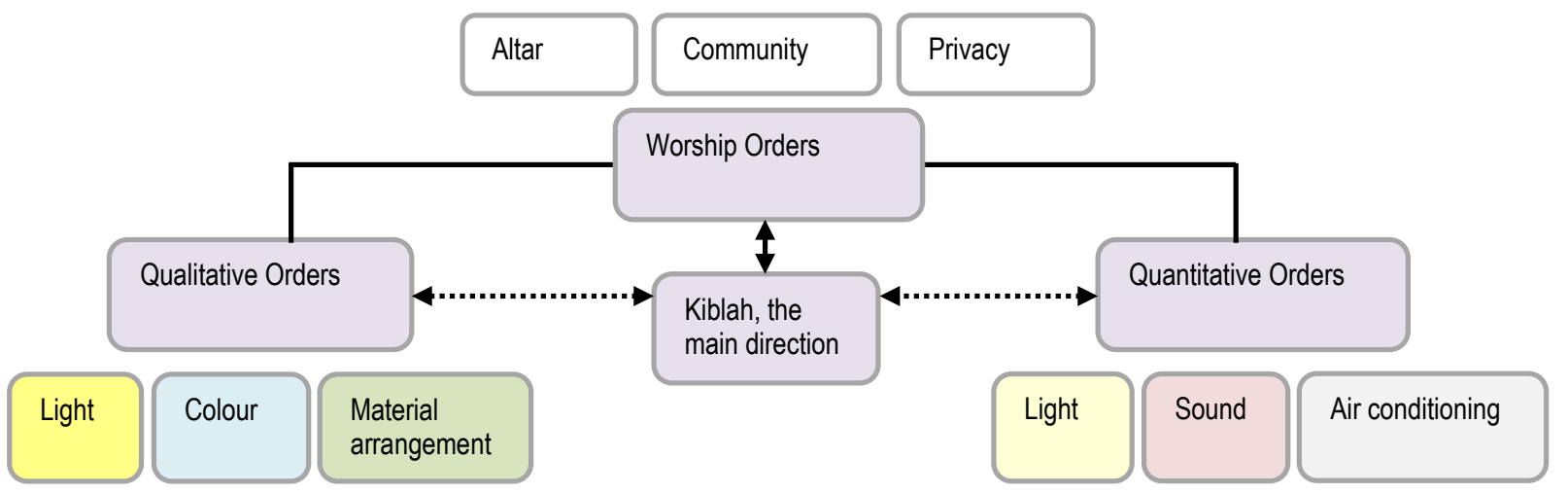

Fig.4. The mosque's orders

\section{Findings}

As it was previously mentioned, in Persian gardens geometrical structure as a combining element would merge natural and artificial elements together.

To avoid mental disturbance and reach privacy, mosques' orders must be arranged in harmony. The worship order in mosques is the combining element to direct toward Kiblah. Each of the orders is connected to some of the five senses and would influence them. In diagrams provided with separation of senses, there are recommended parameters to reach to privacy in environmental orders and ornaments in accordance with psychological principles in Persian gardens.

\subsection{Visual sense}

Successful privacy regulation through both behavioural and environmental mechanisms will provide a comfortable level of visual privacy (Abdul Rahim, 2014) Figs 5 and 6 are presenting some parameters to mosques design focused on visual sense. Aligning visual sense toward kiblah in worshiping orders and preventing existence of disturbing factors are important facts to providing visual privacy in mosques design. 


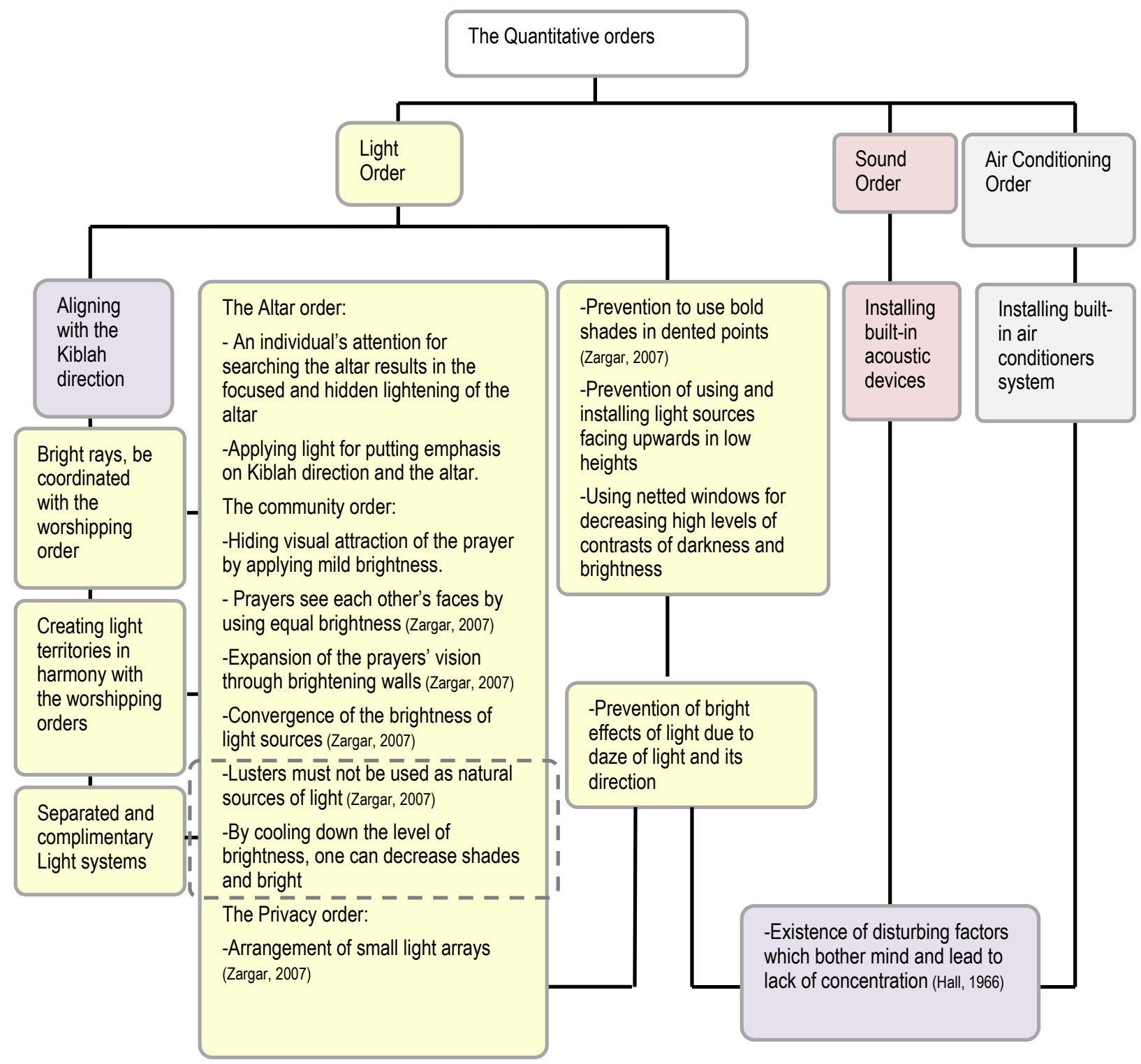

Fig.5. The environmental conditions orders related to visual sense 


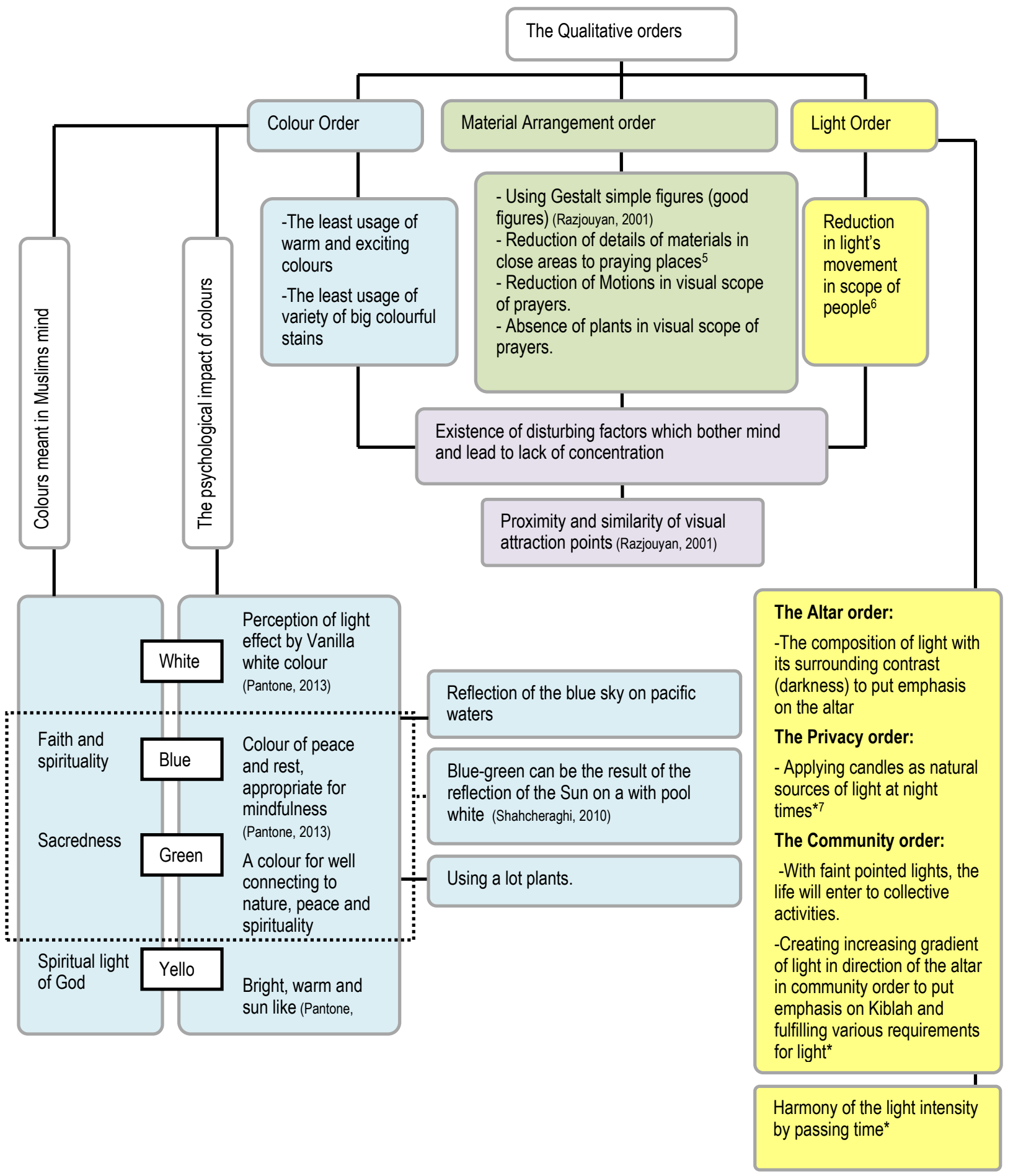

Fig. 6. The ornament order related to visual sense 


\subsection{Auditory sense}

Patterns 7 and 8 are presenting parameters to mosques design focused on auditory sense. Creating acoustic territories and separating the auditory boundaries in harmony by the worship orders, are important facts to provide patterns to achieve auditory privacy in mosque design.

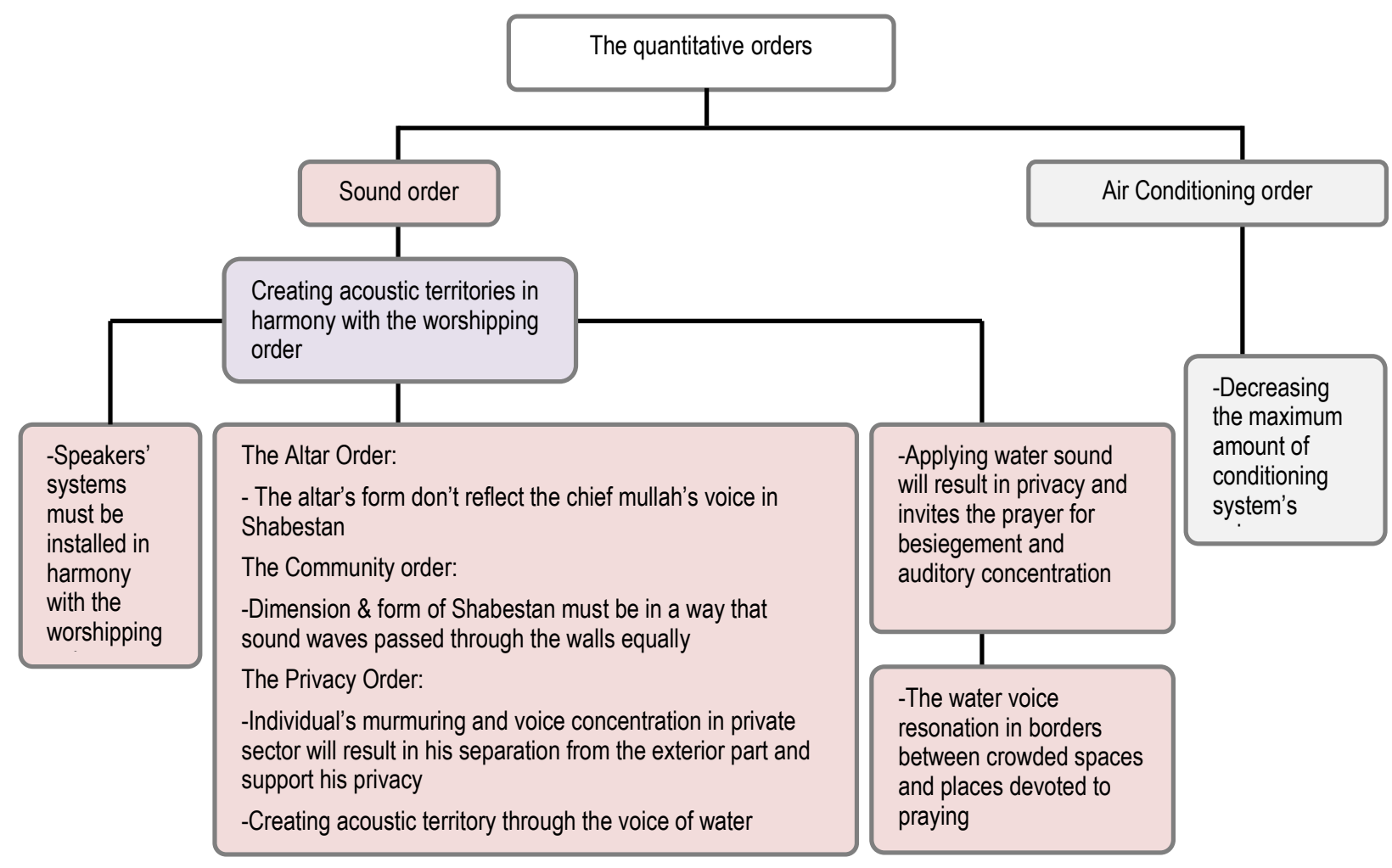

Fig. 7. The environmental conditions orders related to auditory sense

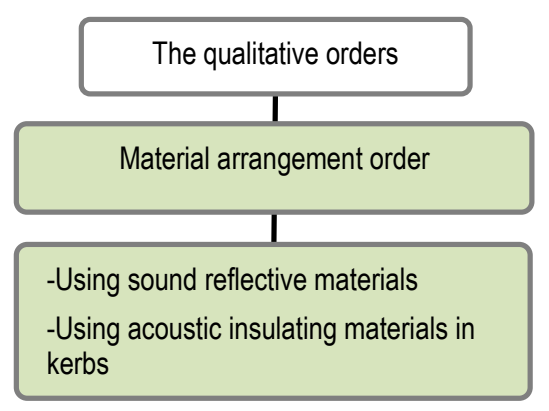

Fig. 8. The ornamental orders related to auditory sense

\subsection{Olfactory sense}

Fig 9 is presenting parameters to mosques design focused on olfactory sense. Creating olfactory territories in harmony by worship orders is an efficient fact to provide olfactory privacy in mosque design. 


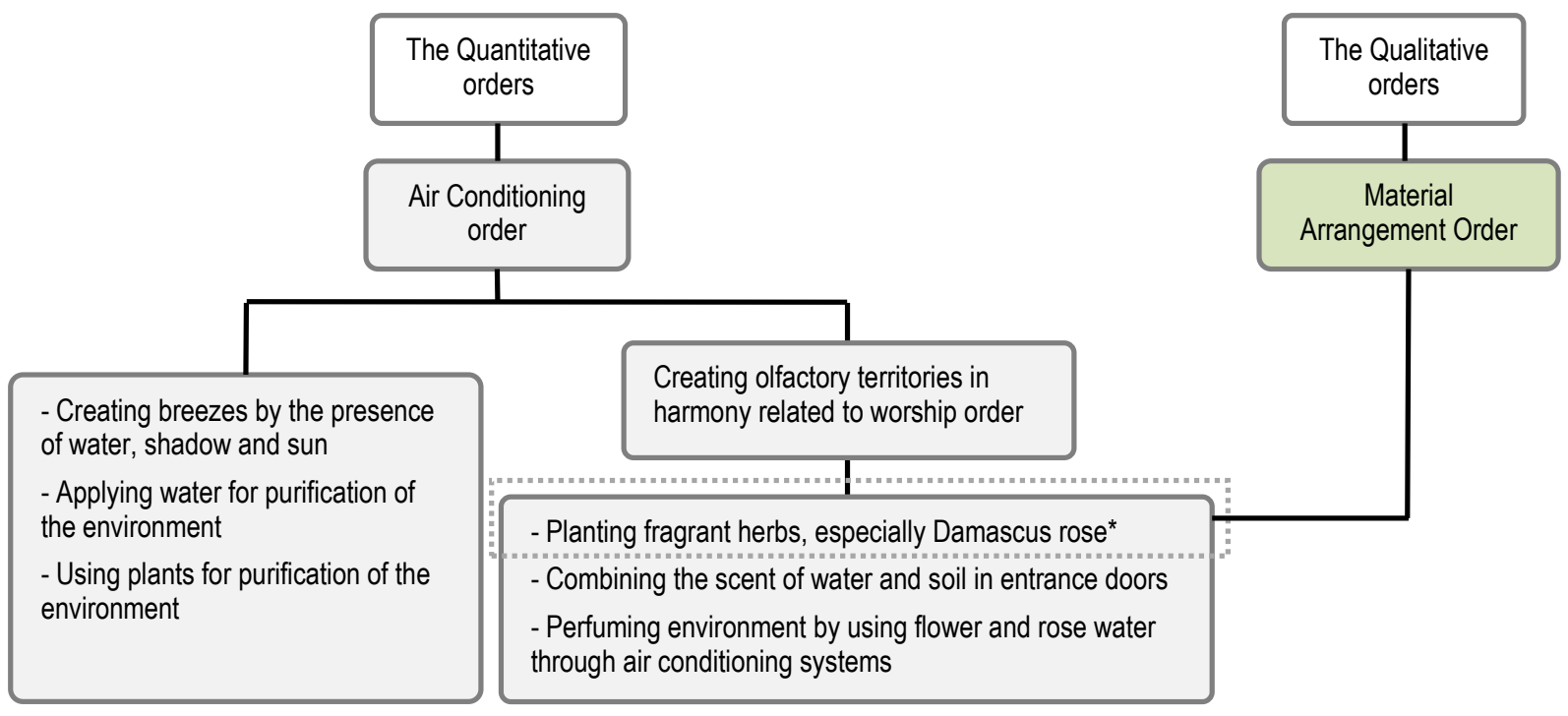

Fig. 9. The environmental conditions orders related to olfactory

\subsection{Tactile sense}

Fig 10 and 11 are presenting design parameters focused on tactile. Creating besiegemen througt tactile sense and creating tactile territories in harmony related to worship orders, are effieccent factors to provide tactil privacy in mosques design.

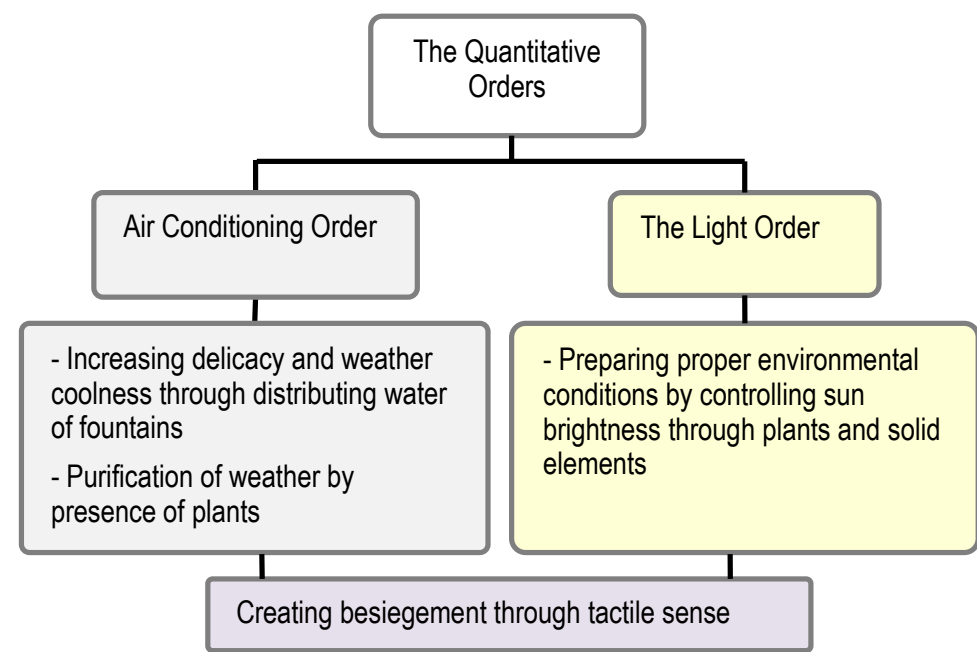

Fig. 10. The environmental conditions orders related to tactile

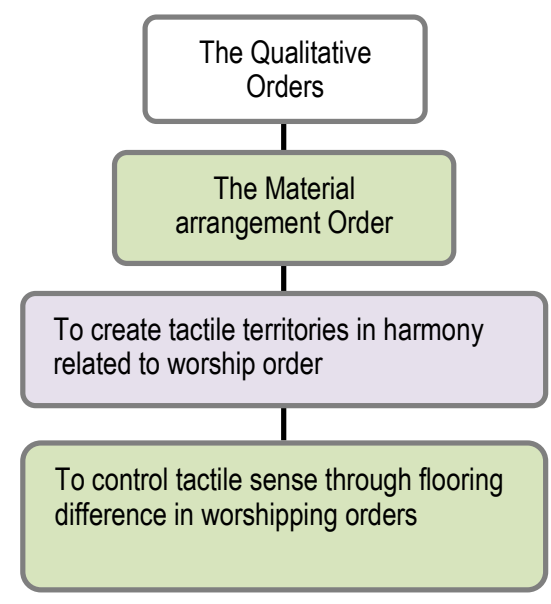

Fig.11. The ornamental orders related to tactile

\section{Discussion and Recommendation}

Among mentioned parameters in patterns of Section 4, common parameters between Persian gardens and mosques are displayed in a new pattern (Fig.12) focused on functions to reach recreate of privacy in mosques. In this pattern, light is considered as a separate order due to its role to mindfulness and heart presence. 


\section{Light}

-Applying sensory capabilities of light in the phase of preparing. -Creation of bright atmosphere in harmony with the worshipping order.

-Using light for putting emphasis on Kiblah direction and the altar.

-Creating increasing gradient of light in direction of the altar in community order to emphasis on Kiblah direction and fulfil various light requirements. ${ }^{*}$

-Effective applying of the candle light as a natural source of light, especially in private order of worship*

-Harmony of the light intensity related to time pass. ${ }^{*}$

\section{Water}

-Applying sensory capabilities of water in the phase of preparing.

-Combining different types of water sounds to invite to peace.* -Creation of acoustic territories in harmony with worshipping system especially a border line for collective unity and privacy.

-Applying water in linear, flowing form.

-Air conditioning and purification.

-Applying reflective feature of water for promotion of peace.

\section{Planting}

-Applying sensory capabilities of herbs and plants in preparing phase.

-Preparing olfactory territories in harmony with worshipping order.

-Perfuming the atmosphere especially with Jasmine and Damascus rose.

-To apply the green colour of plants to promote spirituality -Presence of plants in interior and exterior territories in worshipping places in collective and individual orders of praying.*

-Purification of Air.

- Controlling Shadow and Sun. *

Fig.12 Common ground of mosque orders and physical orders of Persian garden
Affordance of cognition preparing to place
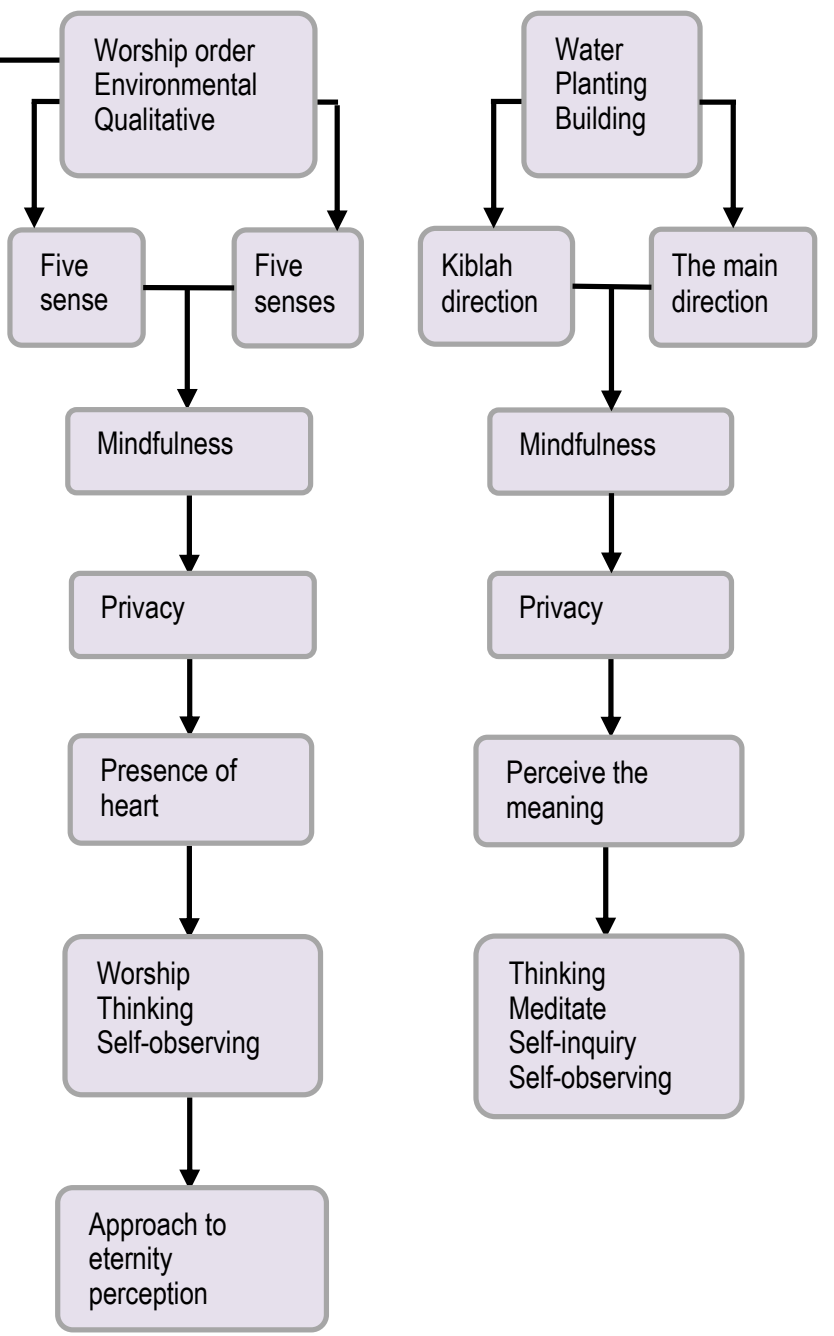

Mindfulness

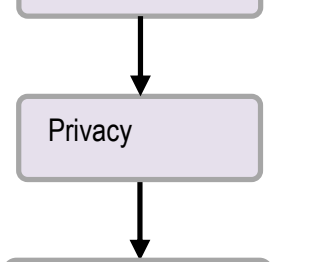

Perceive the meaning

Thinking

Meditate

Self-inquiry

Self-observing

Fig.13 The pattern of approach to privacy in Persian gardens 


\section{Conclusion and Recommendation}

Through the paper preparing privacy and approach to presence have been mentioned based on factors and concepts which should be noticed in mosque design. In the research some physical orders of Islamic Persian gardens have been defined. Also their relationship to the worship order based on the common ground of privacy has been defined.

The conclusion of the paper notices that in creation of privacy during mosques design, attention to way that Iranian gardens privacy has been achieved could be helpful.

Some orders have been found as intersections of privacy meaning in mosques and Persian gardens. They are water order, light order, sound order, plant order, colour order, material order and air conditioning order.

Some recommendation could be defined:

- Notice to intersection of privacy subject between Persian gardens and mosques.

- Preparing orders such as lights, plants, colour, air condition, material order, in suitable situation.

- Notice to preparing privacy parallel to community through worship order in Islam

Notice to main goal which gets to the point Allah worship therefore preparing privacy and community must not disturb presence of heart.

i- The direction which Muslims pray towards it.

ii- The space under the Dome

2- He was an Iranian cleric, philosopher, lecturer, and politician (1919-1979)

iv- Nave: A closed space and usually Preston to collective saying to pray in the mosques.- In near and close distances, one can understand details and texture better (Hall, 1966)- In restaurants, libraries and public places with decreasing movements, one can reduce the level of environmental disturbance (Hall, 1966)- Examples shown by $\left({ }^{*}\right)$ are the outcomes of interviews.

\section{References}

Abdul Rahim, Z. (2014). The influence of culture and religion on visual privacy. Procedia - Social and Behavioral Sciences, 170( 2015$), 537$ - 544.

Altman, I. (1975). The environment and social behaviour. Monterey, CA: Brooks/Cole.

Beheshti, M. G. (2009). Dictionary of Iranian Architecture in Persian Refrence books. Matn.

Dehkhoda, A. (1998). Dehkhoda dictionary. Tehran: Tehran University.

Gharaeia, F.M. N., Rafieian, M., \& Jalalkamali, N. (2012). Investigating cross-cultural differences in the privacy regulation and perception of crowding: Northern and Yazdi women in Iran. Procedia - Social and Behavioral Sciences, 50( 2012), 69 - 78.

Ghaiyoomi Bidhendi, M. S. (2014). The monastery in the fifth century Khorasan. Iranian Architecture, 65-85.

Ghanaati, M. (2015). role of movment and stillness elements in development of Iranian-Islamic cities in order to make optimal satisfaction in human (Case study: bazaar, mosque, house). Procedia - Social and Behavioral Sciences, 201(2015), 201 - 212.

Hall, E.T. (1966). The Hidden Dimension. New York: Doubleday.

Hariri, M. (2009). The provisions of the mosques in Islam. Tehran: Oman.

Jalil, N.A., Yunus, R.M., \& Said, N.S. (2012). Environmental colour impact upon human behaviour: A review. Procedia - Social and Behavioral Sciences, 35(2012), $54-62$.

Kiyani, M. (1990). History of monastery in Iran. Tehran: Tahoory.

Lang, J. (1987). Creating architectural theory: The role of the behavioural sciences in environmental design. New York: Van Nostrand Reinhold Co.

Motahari, M. (2010). Collection 21:Islam and the demands of the modern world. Tehran: Sadra. 
Pantone. (2013). Colors Applied Psychology. Tehran: Beihagh.

Razjouyan, M. (2001). Toward Mihrab: An approach to divine moments. Journal of the School of Architecture and Urban planning Shahid Beheshti University, Soffe, 32, 118-131.

Shahcheraghi, A. (2010). Paradaigms of Paradise. Tehran: Jahad, Tehran University.

Westin, A. (1967). Privacy and freedom. NewYork: Atheneum.

ZafarNavai, K. (2010). Privacy in Islamic mysticism. Islamic Mysticism, 25, 107-121.

Zargar, A. (2007). A Guide For Mosque Architecture. Tehran: Did. 